\title{
Curie per Milligram
}

National Cancer Institute

\section{Source}

National Cancer Institute. Curie per Milligram. NCI Thesaurus. Code C70531.

A unit of specific radioactivity (massic activity) equal to activity of one Curie of the sample with total mass of one milligram. 